\title{
Phytoplankton growth inhibited by the toxic and bacterivorous ciliate Uronema marinum (Protozoa, Ciliophora)
}

\author{
F. L. Schaafsma ${ }^{1}$, L. Peperzak ${ }^{2, *}$ \\ ${ }^{1}$ University of Groningen, 9747 AG Groningen, The Netherlands \\ ${ }^{2}$ Royal Netherlands Institute for Sea Research / NIOZ, Department of Biological Oceanography, 1790 AB Den Burg, \\ The Netherlands
}

\begin{abstract}
The ubiquitous marine ciliate Uronema marinum is mainly bacterivorous. It was therefore surprising that in a ciliate-contaminated experiment the growth rate of the phytoplankton species Emiliania huxleyi was significantly reduced. As $U$. marinum does not ingest E. huxleyi cells, their growth inhibition was probably caused by a toxin secreted by the ciliate, presumably a novel type of chemical interaction between ciliates and phytoplankton. A possible function of toxin secretion is to lyse algal cells that are too large for $U$. marinum to ingest, to increase dissolved organic matter (DOM) concentrations and hence the growth of heterotrophic bacteria, the main food source of $U$. marinum. To test this hypothesis $U$. marinum or the filtrate of $U$. marinum cultures was added to cultures of phytoplankton with different cell sizes. The presence of $U$. marinum or the filtrate of $U$. marinum cultures showed an inhibiting growth effect and a negative effect on the physiology of all species tested although both effects were variable between species. Diatoms appeared less sensitive than non-diatom species. $U$. marinum acclimatization to phytoplankton led to stronger inhibiting effects, presumably from increased toxin production. Bacterial DGGE analysis of $U$. marinum cultures did not reveal known toxic bacteria that might account for the observed negative effects on the phytoplankton. Bacterial growth rates in an E. huxleyi culture increased when $U$. marinum filtrate had been added. In mixed cultures of bacteria, E. huxleyi and $U$. marinum, bacterial abundance first increased, then decreased due to ciliate predation. These findings support the hypothesis that toxin secretion by U. marinum increases non-prey phytoplankton-derived DOM and stimulates the growth of the bacterial prey.
\end{abstract}

KEY WORDS: Uronema marinum · Toxin · Phytoplankton · Bacteria · Growth rate · Physiology · Flow cytometry $\cdot$ FDA $\cdot$ Epifluorescence microscopy

\section{INTRODUCTION}

Ciliates play an important role in aquatic ecosystems. They are usually heterotrophs that feed on bacteria, algae or other planktonic species (Lynn \& Small 1990). As grazers, they are an important part of the decomposition food chain and a link in carbon and nutrient cycling (Lynn \& Small 1990). Some ciliate species are very specific in their diet, preying only on bacteria or algae, just on a few bacterial species or on bacteria with a certain shape (Capriulo 1990). Hence, they are important regulators of aquatic algal and bacterial biomass and species composition (Strom \& Morello 1998).

One of the marine ciliates, Uronema marinum $\mathrm{Du}-$ jardin (Oligohymenophorea, Scuticociliatia), is a globally distributed species that can be found in Antarctic, tropical as well as temperate waters (Coppellotti 1990, Warren \& Scott 2010). Marine ciliates can grow and reproduce in a wide range of temperatures (6 to $30^{\circ} \mathrm{C}$ ) and salinities (10 to $43 \mathrm{~g} \mathrm{~kg}^{-1}$ ) (Hamilton \& Preslan 1969, Jee et al. 2001). Some Uronema spp. can 
even grow (albeit slowly) in water with a salinity $<10 \mathrm{~g} \mathrm{~kg}^{-1}$ (Hamilton \& Preslan 1969). Uronema spp. can be found residing in sediments and are abundant in coastal waters (Anderson et al. 2009). They are free-living ciliates and can be fast swimmers (Pan et al. 2010). Variations in $U$. marinum growth under similar culture conditions can be explained as genetic variability within species as a result of habitat or geographical isolation (Pérez-Uz 1995). The highest growth rates of $U$. marinum $\left(0.25 \pm 0.03 \mathrm{~h}^{-1}\right)$ were found in isolates from an estuarine environment (Pérez-Uz 1995).

Uronema marinum is mainly bacterivorous and can easily be cultured on bacteria. Bacterial genera known to be utilized by $U$. marinum are Chromobacterium, Serratia, Vibrio, Pseudomonas and Micrococcus (Plunket \& Hidu 1978). U. marinum can feed on small phytoplankton as well (Rubin \& Lee 1976). Strom \& Morello (1998) cultured U. marinum on relatively small phytoplankton species such as Isochrysis galbana, Pyrenomonas salina, Mantoniella squamata and the cyanobacterium Synechococcus sp. (Strom \& Morello 1998). Presumably, the buccal cavity of $U$. marinum is unfit to feed on relatively large phytoplankton. A presumed parasitic variant of U. marinum is also histophagous, feeding on fish tissue (Jee et al. 2001, Ahn et al. 2007). Ciliates are eaten by larger zooplankton such as copepods, juvenile fish and foraminiferans (Capriulo et al. 1986).

Recently, the presence of Uronema marinum in a mesocosm experiment led to the decline of Emiliania huxleyi cell numbers. This decline was not caused by grazing of $U$. marinum, but apparently by a toxin secreted by the ciliate (Peperzak et al. unpubl.). So far, toxin secretion by $U$. marinum and the inhibition of growth of other unpreyed, non-competitive planktonic species have not been studied and can possibly play an important role in the life cycle of the ciliate and its place in the microbial ecosystem.

Ciliates in general, including Uronema marinum, are known to secrete various substances. Most ciliates have extrusomes (Pan et al. 2010), which are membrane-bound structures with contents that are discharged outside the cell under certain conditions. Some extrusomes have acid phosphatase activity that aid in the external predigestion of food (Lynn \& Small 2000). Toxicysts, which are another type of extrusomes, contain proteolytic or paralytic toxins that are used by predatory ciliates to capture and ingest prey (Lynn \& Small 2000). A chemical released by protists that inhibits the growth of co-occurring species that are not direct prey or predator is only known when it concerns competitors for, e.g., food sources. Chemi- cals exchanged via cell-to-cell contact, by ciliates of the genus Euplotes for instance, inhibit the growth of competitive ciliates (Guella et al. 2010). The freshwater ciliate Spirostonum ambiguum uses toxins as a chemical defence, but it is suggested that the chemicals are also used to limit the presence of competitors (Buonanno et al. 2012).

A possible function of the presumed Uronema marinum toxin is to kill algal or perhaps other planktonic cells in order to release dissolved organic matter (DOM) in the water, which can then serve as a substrate for heterotrophic bacteria. More DOM means more bacteria and because $U$. marinum is assumed to be mainly bacterivorous, an increase in bacterial abundance would be beneficial for the ciliate. A diagram of this hypothetical cycle is presented in Fig. 1.

In the present study, several experiments have been performed to investigate the interaction between bacteria, phytoplankton and Uronema marinum. To facilitate rapid cell counting, methods for ciliate enumeration by flow cytometry were investigated first. As turbulence can have an effect on protozoan grazing (Shimeta et al. 1995) the effect of turbulence on the growth of $U$. marinum was examined. Next, the effect of the presumed toxin secreted by $U$. marinum on various small and large algae, including potentially edible species, was examined. Furthermore, the effect of $U$. marinum on bacterial composition and bacterial growth was investigated. In a final experiment the growth dynamics of bacteria and phytoplankton were examined in the presence of either U. marinum cells or the presumed U. marinum toxin.

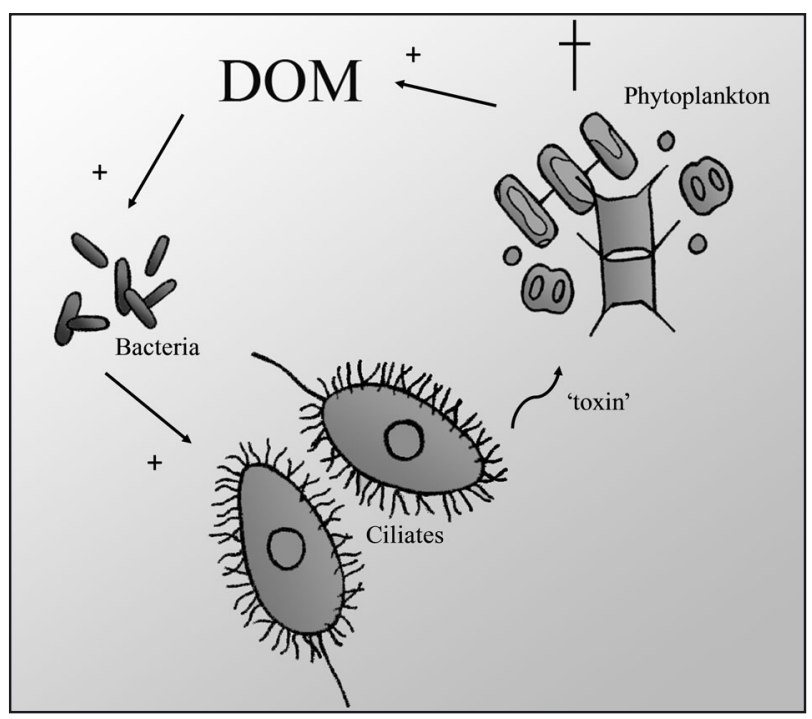

Fig. 1. Hypothesis for the role of 'toxin' secretion by the bacterivorous ciliate Uronema marinum. Phytoplankton cells that are too large to ingest are killed, release dissolved organic matter (DOM) and stimulate bacterial growth 


\section{MATERIALS AND METHODS}

\section{Cultures}

Uronema marinum and co-occurring bacteria were cultured on autoclaved $\mathrm{C} 3+$ medium made of sea water, $\mathrm{KH}_{2} \mathrm{PO}_{4}(3 \mu \mathrm{M}), \mathrm{NH}_{4} \mathrm{Cl}(30 \mu \mathrm{M})$ and $\mathrm{Na}$-pyruvate $(1.5 \mathrm{M})$. In some experiments, $U$. marinum was grown in cultures of phytoplankton species of various sizes (Table 1), obtained from the NIOZ culture collection, in f/2 medium (Guillard \& Ryther 1962) with trace metals added in accordance with Keller et al. (1987). For the diatoms, silicate $(150 \mu \mathrm{M})$ was added to the f/ 2 medium. The salinity of all cultures, ciliate as well as phytoplankton, was between 35 and $36.5 \mathrm{~g}$ $\mathrm{kg}^{-1}$. Cultures were incubated at $15^{\circ} \mathrm{C}$ in a $16: 8 \mathrm{~h}$ light:dark cycle $\left(60 \mu \mathrm{mol}\right.$ photons $\left.\mathrm{m}^{-2} \mathrm{~s}^{-1}\right)$. In a preliminary experiment it was found that the filtrate of a $U$. marinum culture in exponential growth phase did have a negative effect on Emiliania huxleyi growth

Table 1. Cyanobacteria and phytoplankton species used in experiments

\begin{tabular}{|llll|}
\hline Class & Species & Size $(\mu \mathrm{m})$ & Strain \\
\hline Cyanophyceae & Synechococcus & 1 & 543 \\
Prasinophyceae & Micromonas pusilla & 2 & Mp1545 \\
Prymnesiophyceae & Phaeocystis globosa & $4-6$ & Pg22 \\
Prymnesiophyceae & Emiliania huxleyi & $\sim 5$ & 1516 \\
Bacillariophyceae & Chaetoceros calcitrans & $6-8$ & CCMP 1315 \\
Bacillariophyceae & Thalassiosira rotula & $8-55^{\text {a }}$ & RCC766 \\
aiatoms reproduce by binary fission, where each daughter cell receives \\
one parent cell theca as epitheca (outer layer of the cell wall). This leads \\
to a size reduction of the offspring, where variation can be 8 to 10 times \\
the diameter, dependent on the species (Carmelo 1996) \\
\hline
\end{tabular}

Table 2. Flow cytometer settings. Non-fluorescent Uronema marinum and bacterial cells were stained with fluorescein diacetate (FDA) or PicoGreen, respectively. Auto-fluorescent phytoplankton species were not stained. Listed are triggers and thresholds, and bi-plot axes in which the cells were counted. FSC = forward scatter, $\mathrm{SSC}=$ side scatter, $\mathrm{FBG}=$ green fluorescence emission measured at blue excitation $(488 \rightarrow 530 \mathrm{~nm})$, FBR1 = red auto-fluorescence emission measured at blue excitation $(488 \rightarrow 660 \mathrm{~nm})$, FBR2 $=$ far red auto-fluorescence emission measured at blue excitation $(488 \rightarrow>780 \mathrm{~nm})$ and $\mathrm{FBO}=$ orange fluorescence emission measured at blue excitation $(405 \rightarrow 510 \mathrm{~nm})$

\begin{tabular}{|llcl|}
\hline Species & Stain & Trigger \& Threshold & Bi-plot axes \\
\hline Uronema marinum & None & FSC 5000 & SSC $\times$ FBG \\
Uronema marinum & FDA & FBG 200 & FBG $\times$ FBR2 \\
Micromonas pusilla & None & FBR1 5000 & SSC $\times$ FBR1 \\
Phaeocystis globosa & None & FBR1 5000 & FBR1 $\times$ FBO \\
Chaetoceros calcitrans & None & FBR1 1000 & SSC $\times$ FBR1 \\
Thalassiosira rotula & None & FBR1 500 & FSC $\times$ FBR1 \\
Emiliania huxleyi & None & FBR1 2000 & SSC $\times$ FBR1 \\
Bacteria & PicoGreen & FBG 1000 & SSC $\times$ FBG \\
\hline
\end{tabular}

\section{Photosynthetic efficiency}

Quantum efficiency of photosystem II $\left(F_{\mathrm{v}} / F_{\mathrm{m}}\right)$ was used as a proxy for phytoplankton physiology and was measured by pulse amplitude modulation (PAM) fluorimetry using a WATER-ED PAM instrument (Waltz). Samples were dark adapted for $15 \mathrm{~min}$ prior to the measurement.

\section{Cell enumeration}

Phytoplankton and bacteria were enumerated with a FACSCanto II ${ }^{\mathrm{TM}}$ flow cytometer (Becton Dickinson) equipped with a $20 \mathrm{~mW} 488 \mathrm{~nm}$ (Blue) solid state laser providing $9 \times$ $65 \mu \mathrm{m}$ elliptical spots in a $180 \times$ $430 \mu \mathrm{m}$ quartz flow cell. The flow cytometer was calibrated daily with $\mathrm{CST}^{\mathrm{TM}}$ (scatter and fluorescence intensities) and TruCount ${ }^{\mathrm{TM}}$ (flow rate) beads (Becton Dickinson). Flow cytometer and bi-plot axes in which cell clusters were counted are listed in Table 2. Bacteria were enumerated with the same flow cytometer $15 \mathrm{~min}$ after adding to $400 \mu$ l of TE-buffer: $10 \mu \mathrm{TX}-100(40 \times$ diluted), $100 \mu \mathrm{l}$ sample and $10 \mu \mathrm{l}$ PicoGreen ${ }^{\mathrm{TM}}$ (Invitrogen, 500× diluted) (Veldhuis et al. 1997). Phytoplankton was measured using chlorophyll autofluorescence as trigger (Table 2). Uronema marinum cells were initially counted using a $1 \mathrm{ml}$ Sedgewick Rafter chamber 
(Graticules) under a Zeiss Axioplan 2 microscope. A number of techniques for counting $U$. marinum were used. A $2 \mathrm{ml}$ live sample for flow cytometry was incubated for $1 \mathrm{~h}$ with $10 \mu \mathrm{l}$ of fluorescein diacetate (FDA, Invitrogen, $20 \mathrm{mM}$ ). FDA is converted in live cells into green fluorescent fluorescein after the cleavage of acetates by intracellular esterases (Peperzak \& Brussaard 2011). For microscope counts, samples were live or fixed with Lugol's iodine $(10 \mu \mathrm{l}+2 \mathrm{ml}$ sample). A $1 \mathrm{ml}$ sample was counted live to distinguish between live (moving) and presumed dead (non-moving) cells for a comparison with flow cytometry counts.

\section{Effect of turbulence on Uronema marinum growth}

Growth curves were made to establish the effect of turbulence on Uronema marinum growth. Samples from this experiment were used to test different ciliate counting techniques. Four cultures were made by inoculating $1.5 \mathrm{ml}$ of a $U$. marinum culture in 4 flasks with $150 \mathrm{ml} \mathrm{C} 3+$ medium. Duplicate cultures were shaken constantly at $120 \mathrm{rpm}$ on an orbital shaker (Labotech HS500), duplicate controls were not shaken. Instead, they were swirled 3 times daily before sampling.

\section{Predation}

Uronema marinum was added to the cultures listed in Table 1 to investigate if the phytoplankton species were preyed upon. Fluorescently labelled bacteria (FLB) (Sherr \& Sherr 1993) and Synechococcus, which is known to be preyed upon by $U$. marinum (Christaki et al. 1999), were used as a control. Slides for epifluorescence microscopy (Zeiss Axioscope 2) were made at regular intervals by filtering 5 to $10 \mathrm{ml}$ of sample on Sudan-Black stained $0.2 \mu \mathrm{m}$ polycarbonate Poretics ${ }^{\mathrm{TM}}$ filters. The filters were stained for $24 \mathrm{~h}$ in a solution of $8 \mathrm{mg}$ Sudan-Black dissolved in $67 \mathrm{ml}$ of ethanol and diluted with $676 \mathrm{ml}$ of Milli-Q (Millipore ${ }^{\mathrm{TM}}$ ).

\section{Uronema marinum effect on phytoplankton}

To investigate the effect of the presumed Uronema marinum toxin on phytoplankton growth and physiology, U. marinum culture or culture filtrate was added to the species listed in Table 1 (except Synechococcus sp.). C3+ medium (control), U. marinum in
$\mathrm{C} 3+$ culture or culture filtrate was added in equal volumes to phytoplankton cultures. Phytoplankton cell numbers and physiology were measured daily with flow cytometry and PAM, respectively.

In a second experiment, Uronema marinum was not grown in $\mathrm{C} 3+$ but pre-cultured with the same phytoplankton species to which its filtrate was later added (Table 1, except Synechococcus sp.). Sterile sea water (control) or $U$. marinum filtrates were added 1:1 to each phytoplankton culture. Extra nutrients were added at $\mathrm{f} / 2$ concentrations to prevent nutrient limitation. Phytoplankton cell numbers and physiology were measured daily.

\section{Bacterial species composition}

Bacteria in the Uronema marinum cultures served as a food source for the ciliate, but certain species are known to be toxic to phytoplankton and as such can be mistaken for $U$. marinum toxins. To investigate which bacterial and possibly toxic species were present in the $U$. marinum cultures, a DGGE analysis was performed in $6 U$. marinum $\mathrm{C} 3+$ cultures and 4 bacterial cultures which were isolated from a U. marinum culture by dilution series. The oldest $U$. marinum culture was 3 mo old, the youngest was reinoculated a week before the analysis. The oldest cultures had been re-inoculated 2 or 3 times in C3+ medium. The isolated bacteria were cultured on $\mathrm{C} 3+$ and on C6 (15 mM glucose instead of Na-pyruvate). DNA extraction was performed on a $20 \mathrm{ml}$ sample, concentrated on a $0.2 \mu \mathrm{m}$ polycarbonate filter, with the MOBIO Powersoil ${ }^{\mathrm{TM}}$ DNA isolation kit in accordance with the manufacturer's 'maximum yield' protocol. The 16S rRNA encoding gene fragment of bacteria was amplified using PCR with primers 341F (forward + GC-clamp), 907RA (reverse) and 907RC (reverse) in $20\left(1 \mathrm{~min}, 94^{\circ} \mathrm{C} ; 1 \mathrm{~min}, 65^{\circ} \mathrm{C} ; 3 \mathrm{~min}, 72^{\circ} \mathrm{C}\right)$ and $15\left(1 \mathrm{~min}, 94^{\circ} \mathrm{C} ; 1 \mathrm{~min}, 55^{\circ} \mathrm{C} ; 3 \mathrm{~min}, 72^{\circ} \mathrm{C}\right)$ cycles. DGGE was performed in accordance with Schäfer \& Muyzer (2001). A DGGE band extract $(2 \mu \mathrm{l})$ was used as template in $50 \mu \mathrm{PCR}$ reactions using forward primer $341 \mathrm{~F}$ and reverse primers 907RA and 907RC in $20\left(1 \mathrm{~min}, 94^{\circ} \mathrm{C} ; 1 \mathrm{~min}, 55^{\circ} \mathrm{C} ; 3 \mathrm{~min}, 72^{\circ} \mathrm{C}\right)$ and $11\left(1 \mathrm{~min}, 94^{\circ} \mathrm{C} ; 1 \mathrm{~min}, 55^{\circ} \mathrm{C} ; 3 \mathrm{~min}, 72^{\circ} \mathrm{C}\right)$ cycles. Sequencing was performed by Macrogen Europe.

\section{Bacterial growth in lysed phytoplankton culture}

In one of the previous experiments the difference in bacterial cell abundance between Uronema mar- 
inum cultured in $\mathrm{C} 3+$ and in an Emiliania huxleyi culture was a factor of 10. Therefore, bacterial growth was measured in a lysed phytoplankton culture with $\mathrm{C} 3+$ as a control. An E. huxleyi culture was heated to $60^{\circ} \mathrm{C}$ for $20 \mathrm{~min}$ to destroy algal cells, then filtered. The filtrate was diluted $0 \times, 2.5 \times$ and $6.75 \times$ with sterile sea water and used as growth medium. To $10 \mathrm{ml}$ of these different dilutions and to $10 \mathrm{ml} \mathrm{C} 3+$ (control), $1 \mathrm{ml} U$. marinum culture was added that had been concentrated $3 \times$ by centrifugation $(2000 \times$ $g, 20 \mathrm{~min})$. U. marinum and bacteria were counted daily by microscopy and flow cytometry, respectively. The inorganic nutrients were analysed at the beginning and the end of the experiment, according to Peperzak et al. (2011), but were not limiting.

\section{Bacterial growth in phytoplankton-Uronema culture}

To investigate the hypothesis that phytoplankton lysis by Uronema marinum toxins enhances bacterial growth, either $U$. marinum or $U$. marinum filtrate was added to a phytoplankton culture. Sterile sea water (control), U. marinum cultured on Emiliania huxleyi and the filtrate of the latter culture were added in equal volumes to $E$. huxleyi cultures. Nutrients were added at $\mathrm{f} / 2$ concentrations to prevent E. huxleyi nutrient limitation. U. marinum, phytoplankton and bacteria were counted daily by flow cytometry.

\section{Statistics}

Linear regression was performed in Excel ${ }^{\mathrm{TM}}$ version 2007. Repeated measures ANOVA and Tukey's post hoc test (Statistica ${ }^{\mathrm{TM}} 10$ ) was used to test the null hypothesis of no effect between different treatments in growth rate and in the temporal development of cell abundances and PSII efficiencies. The null hypothesis was rejected, i.e. a significant difference between treatments was obtained at $\mathrm{p}<0.05$. In the results of the phytoplankton growth experiments a statistical difference at $\mathrm{p}<0.10$ was also shown to reveal trends (Table 3 ).

\section{RESULTS}

\section{Uronema marinum enumeration}

Microscopy and flow cytometry were compared for the reliable enumeration of live Uronema marinum cells. Linear regression showed that the abundance of unfixed, moving and non-moving ciliate cells counted by microscopy was a factor 2 higher than counts in Lugol-fixed samples (unfixed cell numbers $=2.15 \times$ Lugol cell numbers $+184, r^{2}=0.87$ ). Apparently, swimming cells under a microscope were counted more than once. The abundance of live U. marinum, i.e. cells that were stained with FDA, enumerated by flow cytometry was slightly lower than the abundance in Lugol-fixed samples enumerated by microscopy, which was also confirmed by the comparison (FDA cell numbers $=0.89 \times$ Lugol cell numbers $+65, \mathrm{r}^{2}=$ 0.87 ). It was therefore assumed that FDA-stained cell concentrations obtained from flow cytometer counts are an accurate representation of the abundance of live $U$. marinum cells. $\downarrow \downarrow \downarrow \downarrow>1000 \times$, differences in photosynthetic efficiency $\left(F_{\mathrm{v}} / F_{\mathrm{m}}\right)$ are $\downarrow \leq 0.1, \downarrow \downarrow$ $\leq 0.2, \downarrow \downarrow \downarrow \leq 0.5, \downarrow \downarrow \downarrow \downarrow>0.5$. Statistical difference in growth over $7 \mathrm{~d}$ between the treatment and the control: ${ }^{*} \mathrm{p}<0.10,{ }^{* *} \mathrm{p}<0.05,{ }^{* * *} \mathrm{p}<0.001$. See Table 2 for full species names

\begin{tabular}{|c|c|c|c|c|c|c|}
\hline & \multirow[t]{2}{*}{ Treatment } & \multirow{2}{*}{$\begin{array}{c}\text { Grazed } \\
\text { M. pusilla }\end{array}$} & \multicolumn{4}{|c|}{ Not grazed } \\
\hline & & & P. globosa & C. calcitrans & T. rotula & E. huxleyi \\
\hline \multicolumn{7}{|c|}{ Cell abundance } \\
\hline I & + Uronema & $\downarrow \downarrow \downarrow \downarrow * * *$ & - & $\downarrow * *$ & $\downarrow *$ & $\downarrow * * *$ \\
\hline I & + Filtrate & - & - & $\downarrow$ & $\downarrow * *$ & $\downarrow$ \\
\hline II & + Filtrate & $\downarrow \downarrow * * *$ & $\downarrow \downarrow \downarrow \downarrow *$ & $\downarrow$ & $\downarrow * *$ & $\downarrow \downarrow *$ \\
\hline \multicolumn{7}{|c|}{$F_{\mathrm{v}} / F_{\mathrm{m}}$} \\
\hline I & + Uronema & $\downarrow \downarrow \downarrow$ & $\downarrow$ & $\downarrow \downarrow$ & - & $\downarrow \downarrow \downarrow$ **** \\
\hline I & + Filtrate & $\downarrow$ & $\downarrow$ & $\downarrow$ & - & $\downarrow$ \\
\hline II & + Filtrate & $\downarrow \downarrow \downarrow * *$ & $\downarrow \downarrow \downarrow \downarrow * * *$ & $\uparrow * * *$ & $\downarrow^{* *}$ & $\downarrow \downarrow \downarrow * * *$ \\
\hline
\end{tabular}

\section{Effect of turbulence on Uronema marinum}

Ciliate growth rate in exponential growth phase (first 3 d) was not significantly different between cultures with and without turbulence (Fig. 2). However, in both cultures with turbulence cell numbers declined after $7 \mathrm{~d}$, while the cell numbers in non-turbulent cultures remained stable. This was also found in previous research on other cil- 


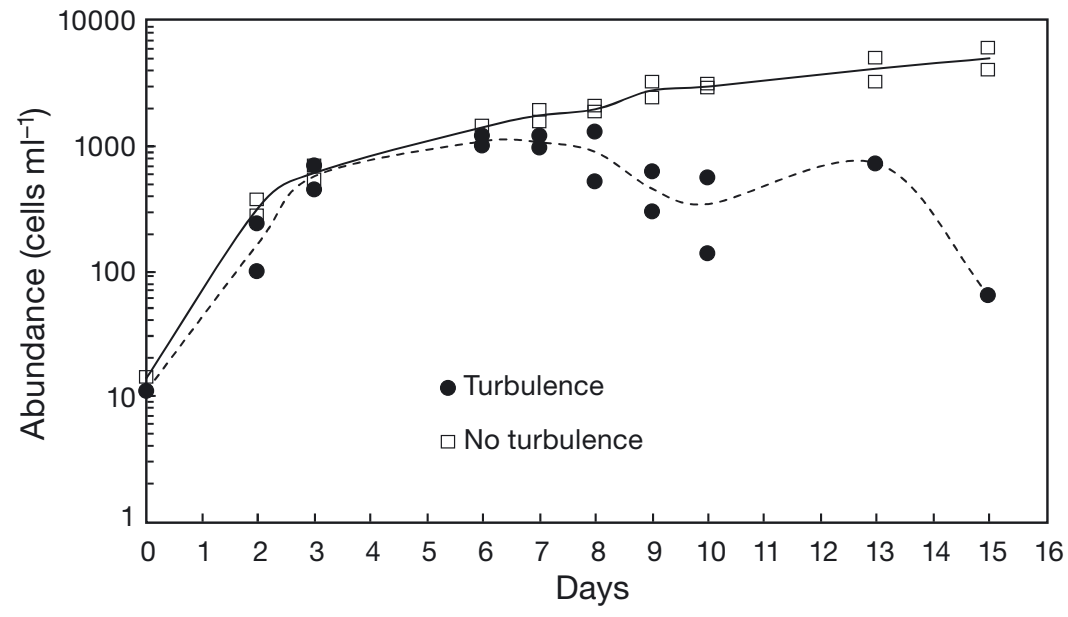

Fig. 2. Comparison of Uronema marinum growth in turbulent and non-turbulent conditions. $U$. marinum abundance was measured by counting ciliates unstained and unfixed using microscopy. Ciliates numbers measured by microscopy after Lugol fixation or by flow cytometry after addition of fluorescein diacetate (FDA) yielded similar growth curves iate species, possibly caused by a reduced ingestion due a change in swimming speed or pattern (Dolan et al. 2003). In all following experiments $U$. marinum was cultured without continuous turbulence.

\section{Predation}

Observations using epifluorescence microscopy demonstrated that Synechococcus and Micromonas pusilla (Fig. 3A,B) and FLB (result not shown) were ingested by Uronema marinum, while Phaeocystis globosa, Thalassiosira rotula (Fig. 3C,D), Chaetoceros calcitrans and Emiliania huxleyi (results not shown) were not.
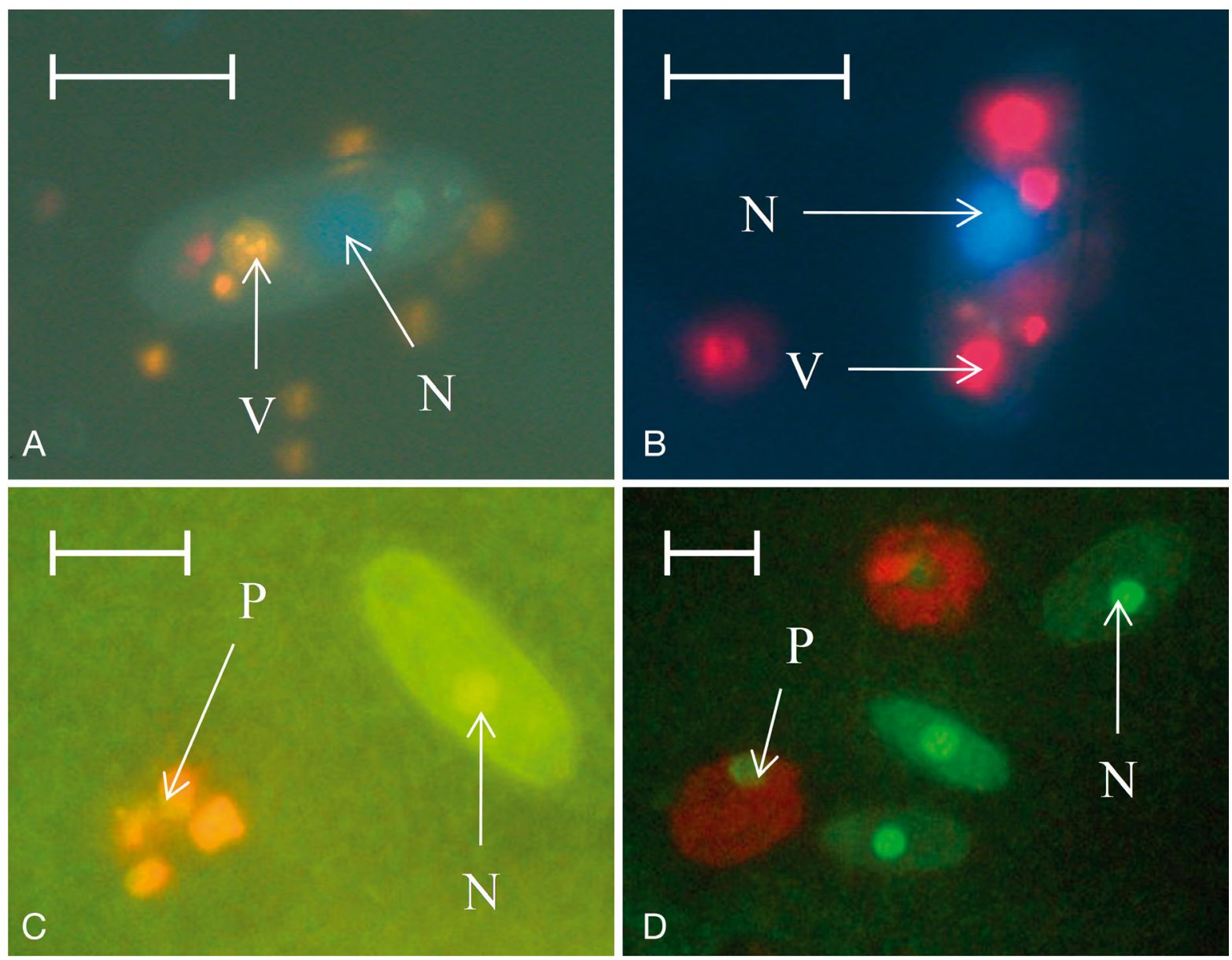

Fig. 3. Images showing ingestion by epifluorescence. (A-D) Examples of Uronema marinum added to different auto-fluorescent plankton species: (A) Synechococcus, (B) Micromonas pusilla, (C) Phaeocystis globosa, (D) Thalassiosira rotula. N = Uronema marinum cell nucleus stained with DAPI $\mathrm{V}=$ vacuole in $U$. marinum cell with ingested fluorescent cell particles in A \& B. C \& D were not ingested by U. marinum. P = phytoplankton cells. Scale bars represent $10 \mu \mathrm{m}$ 


\section{Effect of Uronema marinum on phytoplankton}

Growth of all phytoplankton species tested was negatively affected by the addition of Uronema marinum or $U$. marinum filtrate at least once in both phytoplankton growth experiments (Figs. 4 \& 5, Table 3). This also holds for PSII efficiency, with just one exception $(C$. calcitrans pre-cultured with phytoplankton, Table 3). The effects on different species are however variable within and between experiments. In the filtrate experiments where $U$. marinum had been precultured in the presence of phytoplankton, the negative effects were stronger than when the ciliate had been pre-cultured in $\mathrm{C} 3+$ (Table 3). As expected, the decline in $M$. pusilla abundance was higher in the experiment with $U$. marinum cells, which is due to predation. In most species that were not grazed cell abundance or PSII efficiency declined more in the presence of $U$. marinum compared to its filtrate, probably due to the secretion of the presumed toxin by living ciliates. Interestingly, the diatoms appeared less sensitive than the prasinophyte and the prymnesiophytes. The 'flagellates' showed a decline in growth (up to 1000x) or PSII efficiency (>0.5) in both $U$. marinum filtrates, while the effects of filtrates on diatoms were much less severe (Table 3). For instance, the flagellate decline in PSII efficiency after 1 to $2 \mathrm{~d}$ was dramatic (Fig. 5B,D,J).

\section{Bacterial species composition}

DDGE analysis showed that bacteria present in all Uronema marinum cultures belonged to 3 genera: Fluviicola sp. (Cryomorphaceae), Oceanobacter sp. (Oceanospirillaceae) and Nisaea sp. (Rhodospirillaceae). There were no differences in species composition between young and old cultures, or between C3+ and C6 media.

\section{Bacterial growth in lysed phytoplankton culture}

C3+ culture medium contains only 1 carbon source for bacterial growth. It was, therefore, not surprising that the growth rate of Uronema marinum was higher in an undiluted medium of artificially lysed algal cells (Table 4). Even when this medium was diluted, the bacterial and $U$. marinum cell numbers after $3 \mathrm{~d}$ were higher compared to $\mathrm{C} 3+$ (Fig. 6). Bacterial growth rates in the diluted media of lysed algal cells appeared relatively low compared to $\mathrm{C} 3+$ medium due to grazing by $U$. marinum (Table 4 ).

\section{Bacterial growth in phytoplankton-Uronema culture}

The abundance of bacteria in untreated Emiliania huxleyi cultures was relatively low (Fig. 7A). The addition of Uronema marinum led to a decrease in $E$. huxleyi cells, most probably by lysis due to the ciliate's toxin (Fig. 7B). Phytoplankton lysis provided a substrate for the bacteria and bacterial growth rate increased (Table 5). In addition, bacterial abundance declined again on Day 3 due to the increased predation by $U$. marinum. The filtrate of $U$. marinum also caused a decline of $E$. huxleyi abundance and a concomitant increase in bacterial growth rate and abundance (Fig. 7C). The photosynthetic efficiency decreased directly in the presence of $U$. marinum and after $3 \mathrm{~d}$ in the presence of $U$. marinum filtrate. In the control the photosynthetic efficiency remained stable (results not shown).

\section{DISCUSSION}

\section{Effect of Uronema marinum on phytoplankton and bacterial growth}

Uronema marinum grazes on bacteria, cyanobacteria and small phytoplankton species $(<4 \mu \mathrm{m})$. Apart from Micromonas pusilla, the algal species used in this study were not grazed by U. marinum. Larger phytoplankton species are probably too large for the ciliate's buccal cavity. Strom \& Morello (1998) found that $U$. marinum growth was also supported by the cryptophyte Pyrenomonas salina, which has a length of approximately $10 \mu \mathrm{m}$. However, this does not mean that $P$. salina was preyed upon by $U$. marinum as experiments in the present study showed that $U$. marinum growth can be enhanced by the presence of unpreyed phytoplankton. The decrease in the $P$. salina cell numbers in Strom \& Morello (1998) could be caused by the Uronema-toxin.

Algal abundances and photosynthetic efficiencies decreased in the presence of Uronema marinum cells and after the addition of the filtrate of an $U$. marinum culture. It is likely that the filterable compound, the presumed toxin, caused lysis of the algal cells. Algal lysis was not the result of toxic bacteria because the species present in the $U$. marinum cultures are not known to be algicidal. Apparently there is no effect of the toxin on bacterial species, which could be due to fundamental differences in cell wall composition between eukaryotes and prokaryotes. Differences in cell wall composition between 'flagellates' and dia- 

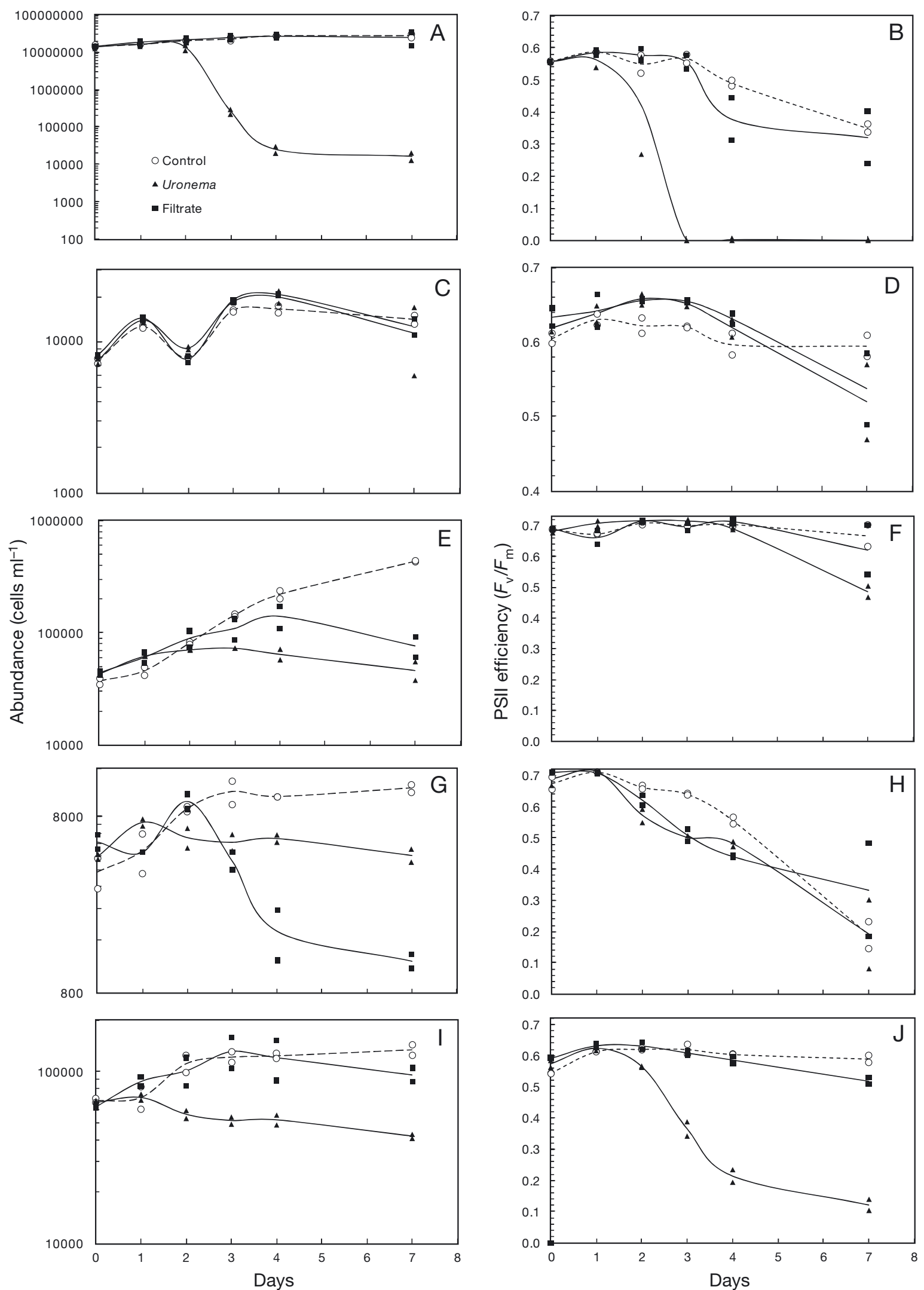

Fig. 4. Effect of Uronema marinum and its filtrate on phytoplankton growth and physiology. C3+ medium, the medium used to grow U. marinum (Control), U. marinum cultured in C3+ (Uronema) or the filtrate of $U$. marinum cultured in C3+ (Filtrate) was added to phytoplankton cultures. (A, $, \mathrm{E}, \mathrm{G}, \mathrm{I})$ Abundance and (B,D,F,H,J) PSII efficiency were measured. (A,B) Micromonas pusilla; (C,D) Phaeocystis globosa; $(\mathrm{E}, \mathrm{F})$ Chaetoceros calcitrans; $(\mathrm{G}, \mathrm{H})$ Thalassiosira rotula; $(\mathrm{I}, \mathrm{J})$ Emiliania huxleyi 

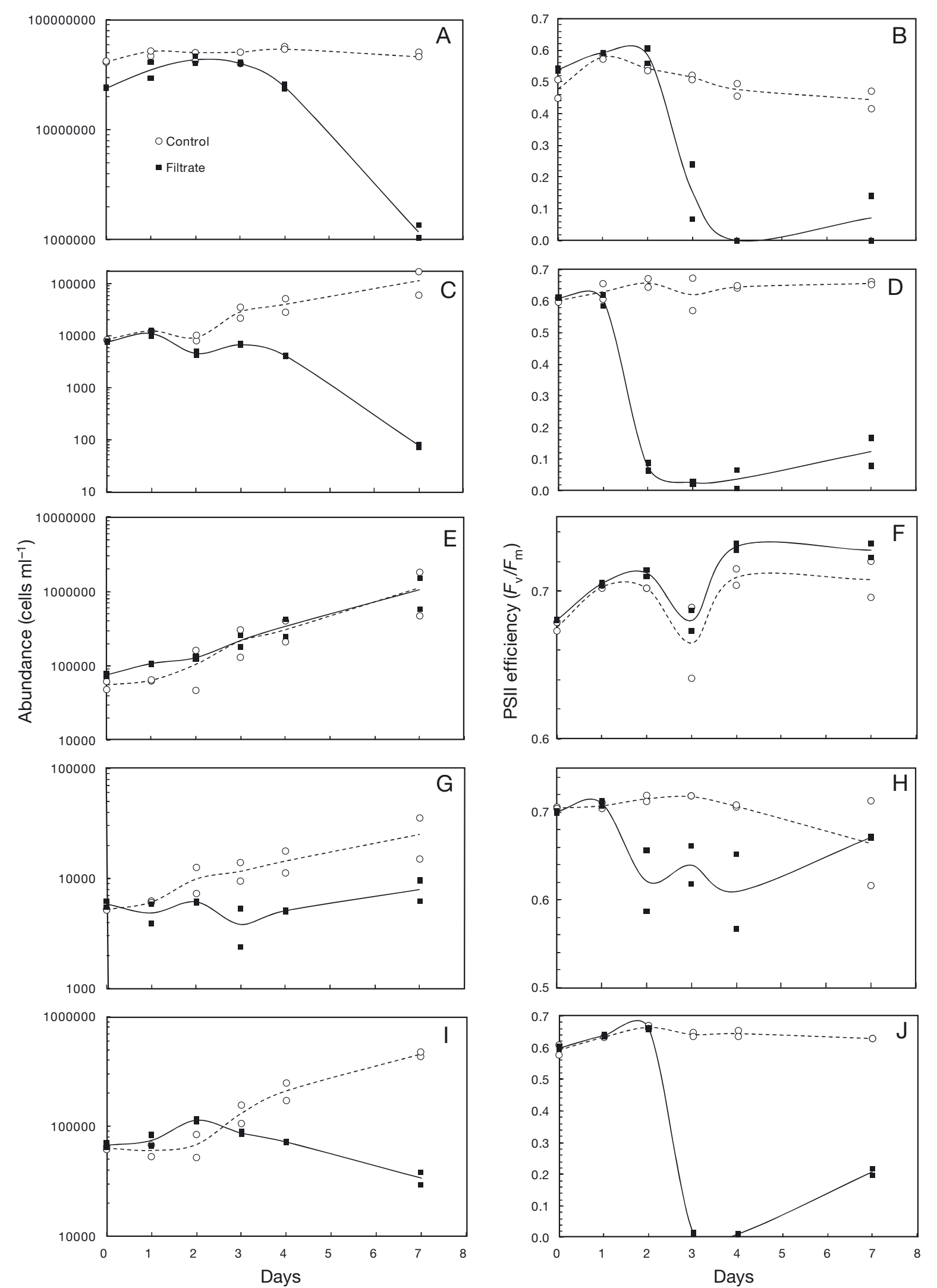

Fig. 5. Effect of Uronema marinum and its filtrate on phytoplankton growth rate and physiology. Sterile sea water (Control) and the filtrate of Uronema marinum cultured in the presence of phytoplankton (Filtrate) was added to phytoplankton cultures. $(\mathrm{A}, \mathrm{C}, \mathrm{E}, \mathrm{G}, \mathrm{I})$ Abundance and $(\mathrm{B}, \mathrm{D}, \mathrm{F}, \mathrm{H}, \mathrm{J})$ PSII efficiency were measured. $(\mathrm{A}, \mathrm{B})$ Micromonas pusilla; $(\mathrm{C}, \mathrm{D})$ Phaeocystis globosa; $(\mathrm{E}, \mathrm{F})$ Chaetoceros calcitrans; $(\mathrm{G}, \mathrm{H})$ Thalassiosira rotula; $(\mathrm{I}, \mathrm{J})$ Emiliania huxleyi 
Table 4. Uronema marinum and bacterial growth rate per day in different culture media. Ciliates and bacteria were grown in a dilution series of a medium of artificially lysed Emiliania huxleyi cells and in C3+

\begin{tabular}{|c|c|c|c|c|}
\hline \multirow[t]{2}{*}{ Species } & \multicolumn{3}{|c|}{ Medium of artificially lysed algal cells } & \multirow[t]{2}{*}{$\mathrm{C} 3+$} \\
\hline & $\begin{array}{c}0 \times \\
\text { diluted }\end{array}$ & $\begin{array}{c}2.5 \times \\
\text { diluted }\end{array}$ & $\begin{array}{c}6.75 \times \\
\text { diluted }\end{array}$ & \\
\hline Bacteria & 0.60 & 0.35 & 0.02 & 0.48 \\
\hline U. marinum & 1.58 & 1.68 & 1.52 & 1.13 \\
\hline
\end{tabular}

toms (Madigan \& Martinko 2006) may also underlie their different susceptibility to the Uronema toxin.

Bacterial abundance in Emiliania huxleyi cultures increased dramatically in the presence of Uronema marinum cells or $U$. marinum filtrate. This can be explained as a result of phytoplankton cell lysis and an increase of DOM, a good substrate for bacterial growth (Romaní \& Sabater 2000), and is in accordance with the hypothetical Uronema-phytoplanktonbacteria cycle (Fig. 1).

\section{Toxin secretion}

Uronema marinum grew better on a phytoplankton-bacteria mixture than on a mixture of bacteria in the synthetic $\mathrm{C} 3+$ culture medium. When $U$. marinum was pre-cultured on $\mathrm{C} 3+$, there was sometimes a negative effect on the phytoplankton by the presence of the ciliates but not of the $U$. marinum filtrate. This could be because growing ciliates in the experi-

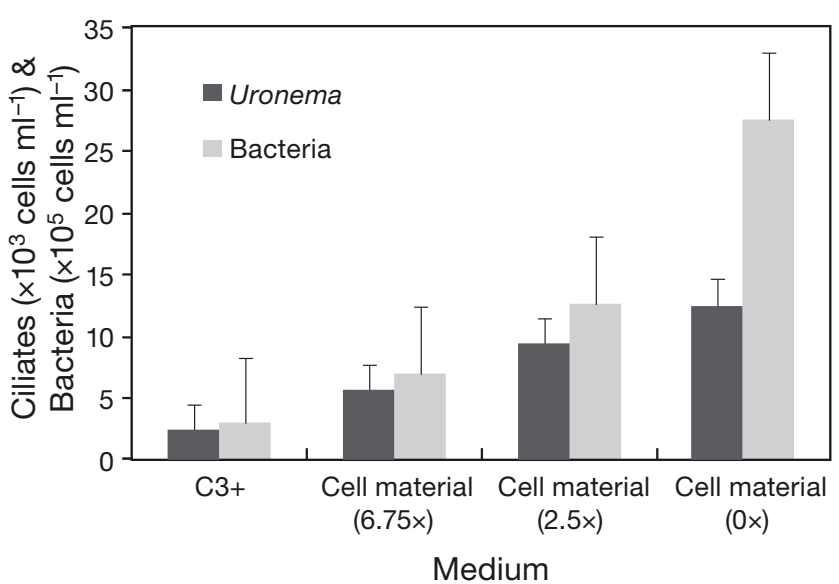

Fig. 6. Uronema marinum and bacterial cell numbers after $3 \mathrm{~d}$ growth in different culture media. Ciliates and bacteria were grown in a medium of artificial lysed Emiliania huxleyi cells which was diluted $0 \times, 2.5 \times$ and $6.75 \times$. Cell numbers were compared with ciliates and bacteria grown in $\mathrm{C} 3+$. Error bars represent $+\mathrm{SE}$
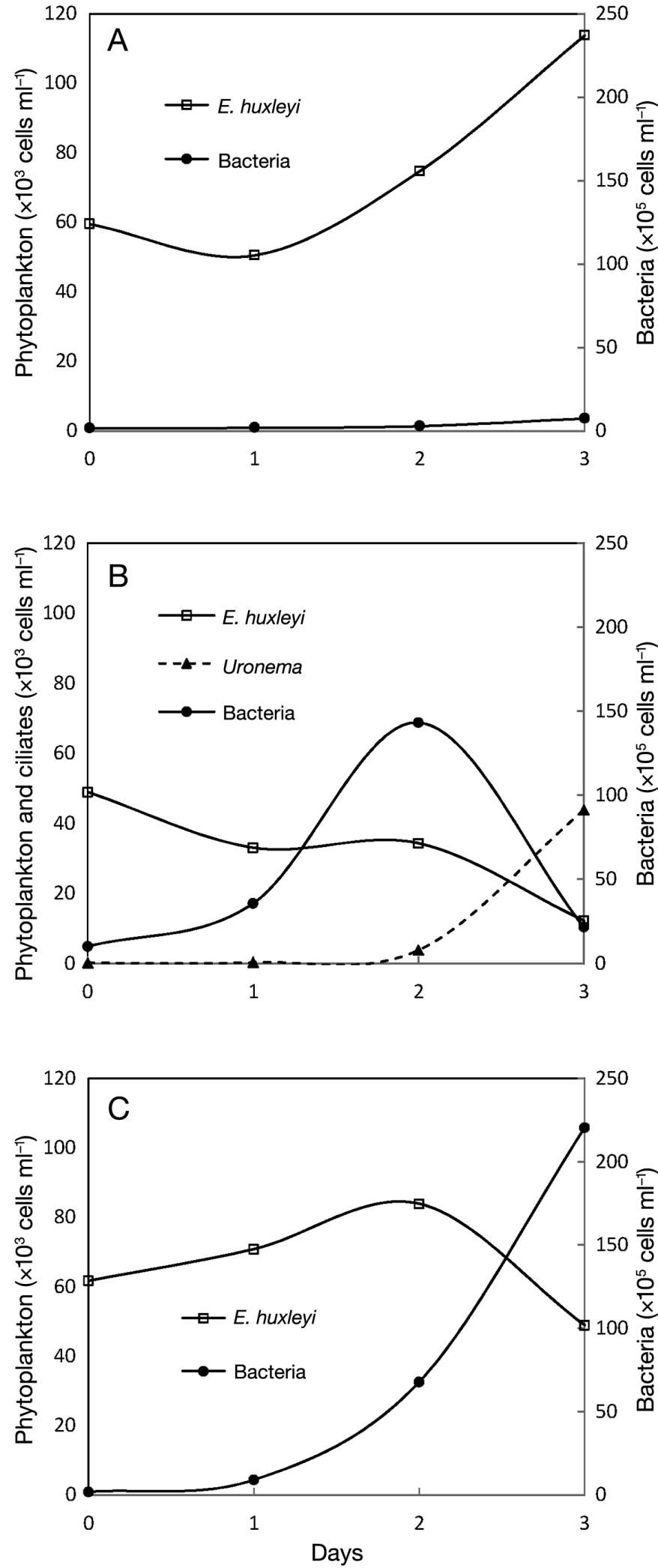

Fig. 7. Bacterial growth in the presence of (A) Emiliania huxleyi (Control), (B) E. huxleyi and Uronema marinum or (C) E. huxleyi and $U$. marinum filtrate 
Table 5. Initial (2 d) growth rates $\left(\mathrm{d}^{-1}\right)$ of Emiliania huxleyi, Uronema marinum and bacteria, under different culture conditions. Sterile sea water (control), U. marinum cultured on E. huxleyi and the filtrate of the latter culture were added to E. huxleyi/bacteria cultures

\begin{tabular}{|lccc|}
\hline & Control & $\begin{array}{c}+U \text {. marinum } \\
\text { cultured in } \\
\text { E. huxleyi }\end{array}$ & $\begin{array}{c}\text { f U. marinum } \\
\text { filtrate }\end{array}$ \\
\hline Phytoplankton & 0.11 & -0.18 & 0.15 \\
Bacteria & 0.29 & 1.33 & 1.82 \\
U. marinum & & 2.22 & \\
\hline
\end{tabular}

ments increased the total toxin concentration. This does not explain the effect on the growth rate of Thalassiosira rotula on which the $U$. marinum filtrate had a greater negative effect after $2 \mathrm{~d}$ incubation.

Negative effects were stronger when Uronema marinum was pre-cultured on phytoplankton. A possibility is that when $U$. marinum was cultured with phytoplankton, acclimatization to phytoplankton triggered toxin production or toxin release. So far, such an interaction has only been studied with toxins released by prey in defence of predators. Assuming that defence mechanisms are costly, activating toxin production only in the presence of a predator can reduce these costs (Van Donk et al. 2011). In the case of $U$. marinum, the toxin would only be produced when a potential prey is present.

\section{Known secretion by Uronema marinum}

At this point, it is unclear whether the presumed toxin is an enzyme, which are known to be secreted by Uronema marinum, or some other chemical compound. Some ciliates expel chemicals that are involved in predator-prey interactions (Wolfe 2000, Tillmann 2004, Hartz et al. 2008, Roberts et al. 2011). Phagocytic protists can recognize their prey by differences in cell surface composition. There are also chemical cues released by prey which cause a motile response in protists (Roberts et al. 2011). Some phytoplankton species can recognize and react on chemicals released by predators by growing grazer resistant morphologies (Lürling \& Von Elert 2001, Long et al. 2007). It is unknown if chemicals released by ciliates can also have an effect on co-occurring species that are not their prey, predator or competitor. There are however studies where, e.g., the toxin euplotin C, produced by the ciliate Euplotes crassus, inhibits the growth or even kills non-aquatic eukaryotic organisms such as pathogenic protozoa, yeasts, bacteria and even human tumor cells (Savoia et al. 2004, Cervia et al. 2006). Human tumor cells are also killed by climacostol produced by the freshwater ciliate Climacostomum virens (Buonanno et al. 2008).

There are several enzymes (proteases and phosphatases) known to be secreted by Uronema marinum. The presumed parasitic variant of $U$. marinum causes scuticociliatosis in fish, a disease caused by invading ciliates that destroy fish tissue. In parasitic diseases proteases play an important role in pathogenicity (Lee et al. 2003) for instance by facilitating host tissue invasion (Kwon et al. 2002). U. marinum is known to secrete a metalloprotease. In some parasitic protozoans, metalloprotease is important for invasion and degradation of host tissues and therefore essential for the progress of the disease (Lee et al. 2003). Besides a metalloprotease, U. marinum also secretes cathepsin L-like cysteine protease. In parasitic organisms, this protease functions in the degradation of intracellular proteins, host-parasite attachment, immuno-evasion, excystment/encystment and the processing of proteins (Ahn et al. 2007). It could be possible that the presumed $U$. marinum toxin that inhibited the growth of E. huxleyi is a phosphatase or a protease.

In a recent study, Shimeta et al. (2012) discovered that biofilm associated ciliates had a variety of effects on the settlement of marine invertebrate larvae. For instance, the settlement of the tube worm Galeolaria caespitosa and the blue mussel Mytilus galloprovincialis was significantly reduced by the presence of bacteria and ciliates compared to the presence of a pure bacterial biofilm (Shimeta et al. 2012). Uronema marinum was part of the biofilm assemblage and it can be speculated that its toxins produced the negative effects on larval settlement and post-settlement mortality.

\section{Implications}

To further understand the mechanism of the Uronema-phytoplankton-bacteria cycle it is necessary to isolate and identify the toxic compound secreted by $U$. marinum. Additionally, it would be interesting to investigate the cellular localization of the extrusomes containing the toxin and the physiological mechanism of their discharge. Comparable studies have been performed on the chemical defence of heterotrich ciliates (Miyake et al. 2003, Buonanno et al. 2012). Toxin concentrations as well as fluxes of carbon from phytoplankton to bacteria and Uronema should be quantified. It would be helpful to study the 
range of environmental conditions under which the toxin has an effect on phytoplankton in order to develop a standard method for further research. To better understand the ecological implications the effects of $U$. marinum toxin on taxonomically different phytoplankton groups should be examined further. Also, the effect on other planktonic taxa such as other ciliates and on ciliate predators should be investigated. By comparison, toxic phytoplankton species can be harmful to different groups of organisms. The alga Prymnesium parvum for example, is toxic to bacteria, other phytoplankton and ciliates (Fistarol et al. 2003).

The natural abundance of ciliated protozoa varies from $10^{2}$ to $>10^{6}$ cells $\mathrm{ml}^{-1}$, with highest densities found in the sediment surface or at the oxic/anoxic interface (Glud \& Fenchel 1999, Dupuy et al. 2011). In a study of a large biofilm of sulphur bacteria, Uronema spp. cell densities reached $9 \times 10^{4} \mathrm{cells} \mathrm{ml}^{-1}$ (Glud \& Fenchel 1999). In the present study, highest $U$. marinum cell densities $\left(>10^{4}\right.$ cells $\left.\mathrm{ml}^{-1}\right)$ were obtained when the ciliate was cultured on a medium of lysed algal cells. In situ growth rates of ciliates have been estimated or calculated using frequency of cell division (Gilron \& Lynn 1989, Carrick et al. 1992). Carrick et al. (1992) estimated ciliate growth rates of 0 to $2.28 \mathrm{~d}^{-1}$. For tintinnine ciliate species in situ growth rates of $-2.55 \mathrm{~d}^{-1}$ have been found (Gilron \& Lynn 1989).

Bacterial concentrations $>10^{5}$ cells $\mathrm{ml}^{-1}$ can sustain Uronema marinum growth, although growth parameters differ depending on bacterial species composition and the preference of the ciliates for certain bacterial prey (Pérez-Uz 1996). Bacterial abundances in sea water generally lie between $10^{5}$ and $10^{7}$ cells $\mathrm{ml}^{-1}$, which is similar to bacterial concentrations reached in this study. Therefore, in the present study, the abundances of $U$. marinum and bacteria, as well as the ciliate's growth rate, were comparable to data obtained in field studies.

When Uronema marinum grow in biofilms, dispersion of its toxin may be relatively low compared to a pelagic environment (Shimeta et al. 2012). This means that in future ecological laboratory studies of $U$. marinum and its toxin a distinction should be made between pelagic and benthic or biofilm habitats.

Predator-prey interactions in general are very complex and remain difficult to understand (Olson \& Lessard 2010). Many studies focussed on phytoplankton defence mechanisms and protist prey selection (Wolfe 2000, Granéli \& Johansson 2003, Strom et al. 2003, Tillmann 2004, Roberts et al. 2011). The present study on Uronema marinum adds a new dimension to predator-prey interactions, where chemical compounds have an effect on co-occurring species that are not directly preyed upon or are direct competitors. The role of ciliates in phytoplankton community composition and nutrient cycling (Lynn \& Small 1990, Strom \& Morello 1998) may be different then hitherto assumed, increasing the complexity of already dynamic and complex aquatic food webs.

Acknowledgements. We gratefully acknowledge the help of Dr. Genoveva Esteban (Queen Mary University, London, UK) and Dr. Xiaozhong $\mathrm{Hu}$ (Ocean University of China, Qingdao, China) for identifying Uronema marinum. We are also very thankful for the help of the following NIOZ personnel: phytoplankton strains were provided by Josje Snoek; fluorescent bacteria and assistance with epifluorescence microscopy was provided by Govert van Noort; nutrients were analysed by Sharyn Crayford; bacterial DGGE analysis was performed by Dennis Mosk, Julie Ogier and Judith van Bleijswijk. Anna Noordeloos, Felicia Arenoe, Eveline Garritsen, Alma Lamers-Rutkauskaite, Santiago Gonzalez, Isabel van der Star, Peter Paul Stehouwer, Douwe Maat and Cees van Slooten have been of great help in the laboratory. We thank Prof. Dr. Anita Buma and 3 anonymous reviewers for commenting on previous versions of the manuscript.

\section{LITERATURE CITED}

Ahn SJ, Seo JS, Kim M, Jeon SJ and others (2007) Cloning, site-directed mutagenesis and expression of cathepsin L-like cysteine protease from Uronema marinum (Ciliophora, Scuticociliatida). Mol Biochem Parasitol 156: 191-198

Anderson SA, Hulston DA, McVeagh SM, Webb VL, Smith PJ (2009) In vitro culture and cryopreservation of Uronema marinum isolated from farmed New Zealand groper (Polyprion oxygeneios). J Microbiol Methods 79: 62-66

Buonanno F, Quassinti L, Bramucci M, Armantini C and others (2008) The protozoan toxin climacostol inhibits growth and induces apoptosis of human tumor cell lines. Chem Biol Interact 176:151-164

- Buonanno F, Guella G, Strim C, Ortenzi C (2012) Chemical defence by mono-prenyl hydroquinone in a freshwater ciliate, Spirostomum ambiguum. Hydrobiologica 684: 97-107

Capriulo GM (1990) Feeding-related ecology of marine protozoa. In: Capriulo GM (ed) Ecology of marine protozoa. Oxford University Press, New York, NY, p 186-259

Capriulo GM, Taveras J, Gold K (1986) Ciliate feeding: effect of food presence or absence on occurrence of striae in tintinnids. Mar Ecol Prog Ser 30:145-158

Carmelo TR (1996) Identifying marine diatoms and dinoflagellates. Academic Press, San Diego, CA

> Carrick HJ, Fahnenstiel GL, Taylor WD (1992) Growth and production of planktonic protozoa in Lake Michigan: in situ versus in vitro comparisons and importance to food web dynamics. Limnol Oceanogr 37:1221-1235

Cervia D, Martini D, Garcia-Gil M, Di Giuseppe G, Guella G, Dini F, Bagnoli P (2006) Cytotoxic effects and apop- 
totic signalling mechanisms of the sesquiterpenoid euplotin C, a secondary metabolite of the marine ciliate Euplotes crassus, in tumor cells. Apoptosis 11:829-843

Christaki U, Jacquet S, Dolan JR, Vaulot D, Rassoulzadegan F (1999) Growth and grazing on Prochlorococcus and Synechococcus by two marine ciliates. Limnol Oceanogr 44:52-61

Coppellotti O (1990) Description of Uronema marinum (Ciliophora, Scuticociliatida) from the Antarctica and observations on the nuclear events in conjugation. Polar Biol 10:365-371

> Dolan JR, Sall N, Metcalfe A, Gasser B (2003) Effects of turbulence on the feeding and growth of a marine oligotrich ciliate. Aquat Microb Ecol 31:183-192

> Dupuy C, Talarmin A, Hartmann HJ, Delmas D, Courties C, Marquis E (2011) Community structure and grazing of the nano-microzooplankton on the continental shelf of the Bay of Biscay. Estuar Coast Shelf Sci 95:1-13

Fistarol GO, Legrand C, Granéli E (2003) Allelopathic effect of Prymnesium parvum on a natural plankton community. Mar Ecol Prog Ser 255:115-125

Gilron GL, Lynn DH (1989) Estimates of in situ population growth rates of four tintinnine ciliate species near Kingston Harbour, Jamaica. Estuar Coast Shelf Sci 29: $1-10$

Glud RN, Fenchel T (1999) The importance of ciliates for the interstitial solute transport in benthic communities. Mar Ecol Prog Ser 186:87-93

Granéli E, Johansson N (2003) Increase in the production of allelopathic substances by Prymnesium parvum cells grown under N- or P-deficient conditions. Harmful Algae 2:135-145

> Guella G, Skropeta D, Di Giuseppe G, Dini F (2010) Structures, biological activities and phylogenetic relationships of terpenoids from marine ciliates of the genus Euplotes. Mar Drugs 8:2080-2116

Guillard RRL, Ryther J (1962) Studies of marine plankton diatoms. Can J Microbiol 8:229-239

Hamilton RD, Preslan JE (1969) Cultural characteristics of a pelagic marine hymenostome ciliate, Uronema sp. J Exp Mar Biol Ecol 4:90-99

Hartz AJ, Sherr BF, Sherr EB (2008) Using inhibitors to investigate the involvement of cell signaling in predation by marine phagotrophic protists. J Eukaryot Microbiol 55:18-21

> Jee BY, Kim YC, Park MS (2001) Morphology and biology of parasite responsible for scuticociliatosis of cultured olive flounder Paralichthys olivaceus. Dis Aquat Org 47:49-55

Keller MD, Selvin RC, Claus W, Guillard RRL (1987) Media for the culture of oceanic ultraphytoplankton. J Phycol 23:633-638

Kwon SR, Kim CS, Ahn KJ, Cho JB, Chung JK, Lee HH, Kim $\mathrm{KH}$ (2002) Proteases in cell lysate of Uronema marinum (ciliate: Scuticociliatida), an opportunistic pathogen of cultured olive flounder (Paralichthys olivaceus). J Fish Sci Technol 5:145-149

> Lee EH, Kim CS, Cho JB, Ahn KJ, Kim KH (2003) Measurement of protease activity of live Uronema marinum (Ciliata: Scuticociliatida) by fluorescence polarization. Dis Aquat Org 54:85-88

> Long JD, Smalley GW, Barsby T, Anderson TB, Hay ME (2007) Chemical cues induce consumer-specific defences in a bloom-forming marine phytoplankton. Proc Natl Acad Sci USA 104:10512-10517

> Lürling M, Von Elert E (2001) Colony formation in Scene- desmus: no contribution of urea in induction by lipophilic Daphnia exudates. Limnol Oceanogr 46:1809-1813

Lynn DH, Small EB (1990) Phylum Ciliophora. In: Margulis L, Corliss JO, Melkonian M, Chapman DJ (eds) Handbook of protoctista. Jones \& Bartlett Publishers, Boston, MA, p 498-523

Lynn DH, Small EB (2000) Phylum Ciliophora. In: Lee JJ, Leedale GF, Bradbury P (eds) An illustrated guide to the protozoa, 2nd edn. Society of Protozoologists, Lawrence, KS, p 371-656

Madigan MT, Martinko JM (2006) Brock biology of microorganisms, 11th edn. Prentice Hall, Upper Saddle River, NJ

Miyake A, Buonanno F, Saltalamacchia P, Masaki ME, Lio H (2003) Chemical defence by means of extrusive cortical granules in the heterotrich ciliate Climacostonum virens. Eur J Protistol 39(1):25-36

> Olson MB, Lessard EJ (2010) The influence of the Pseudonitzschia toxin, domoic acid, on microzooplankton grazing and growth: a field and laboratory assessment. Harmful Algae 9:540-547

Pan H, Huang J, Hu X, Fan X, Al-Rasheid KAS, Song W (2010) Morphology and SSU rRNA gene sequences of three marine ciliates from Yellow Sea, China, including one new species Uronema heteromarinum nov. spec. (Ciliophora, Scuticociliatida). Acta Protozool 49:45-59

Peperzak L, Brussaard CPD (2011) Flow cytometric applicability of fluorescent vitality probes on phytoplankton. J Phycol 47:692-702

Peperzak L, Timmermans KR, Wernand MR, Oosterhuis S, Van der Woerd HJ (2011) A mesocosm tool to optically study phytoplankton dynamics. Limnol Oceanogr Methods 9:232-244

Pérez-Uz B (1995) Growth rate variability in geographically diverse clones of Uronema (Ciliophora: Scuticociliatida). FEMS Microbiol Ecol 16:193-204

Pérez-Uz B (1996) Bacterial preferences and growth kinetic variation in Uronema marinum and Uronema nigricans (Ciliophora: Scuticociliatia). Microb Ecol 31:189-198

Plunket L, Hidu H (1978) The role of Uronema marinum (Protozoa) in oyster hatchery production. Aquaculture 15:219-225

Roberts E, Legrand C, Steinkes M, Wootton EC (2011) Mechanisms underlying chemical interactions between predatory planktonic protists and their prey. J Plankton Res 33:833-841

Romaní AM, Sabater S (2000) Influence of algal biomass on extracellular enzyme activity in river biofilms. Microb Ecol 40:16-24

> Rubin HA, Lee JJ (1976) Informational energy flow as an aspect of the ecological efficiency of marine ciliates. J Theor Biol 62:69-91

Savoia D, Avanzini C, Allice T, Callone E, Guella G, Dini F (2004) Antimicrobial activity of euplotin $C$, the sesquiterpene taxonomic marker from the marine ciliate Euplotes crassus. Antimicrob Agents Chemother 48:3828-3833

Schäfer H, Muyzer G (2001) Denaturing gradient gel electrophoresis in marine microbial ecology. In: Paul JH (eds) Methods in microbiology, Vol 30. Marine microbiology. Academic Press, San Diego, CA, p 425-468

Sherr EB, Sherr BF (1993) Protistan grazing rates via uptake of fluorescently labelled prey. In: Kemp PF, Sherr BF, Sherr EB, Cole JJ (eds) Handbook of methods in aquatic microbial ecology. Lewis Publishers, Boca Raton, FL, p 695-701 
Shimeta J, Jumars PA, Lessard EJ (1995) Influences of turbulence on suspension feeding by planktonic protozoa; experiments in laminar shear fields. Limnol Oceanogr 40:845-859

Shimeta J, Cutajar J, Watson MG, Vlamis T (2012) Influences of biofilm-associated ciliates on the settlement of marine invertebrate larvae. Mar Ecol Prog Ser 449: $1-12$

Strom SL, Morello TA (1998) Comparative growth rates and yields of ciliates and heterotrophic dinoflagellates. J Plankton Res 20:571-584

Strom SL, Wolfe G, Holmes J, Stecher H, Schimeneck C, Lambert S, Moreno E (2003) Chemical defense in the microplankton. I: Feeding and growth rates of heterotrophic protists on the DMS-producing phytoplankter Emiliania huxleyi. Limnol Oceanogr 48:217-229

Editorial responsibility: James McClintock, Birmingham, Alabama, USA
Tillmann U (2004) Interactions between planktonic microalgae and protozoan grazers. J Eukaryot Microbiol 51: $156-168$

> Van Donk E, Ianora A, Vos M (2011) Induced defences in marine and freshwater phytoplankton: a review. Hydrobiologia 668:3-19

> Veldhuis MJW, Cucci TL, Sieracki ME (1997) Cellular DNA content of marine phytoplankton using two new fluorochromes: taxonomic and ecological implications. J Phycol 33:527-541

Warren A, Scott F (2010) World register of marine species. Available at www.marinespecies.org/aphia.php? $\mathrm{p}=$ taxdetails\&id=172341 (accessed 18 Feb 2012)

Wolfe GV (2000) The chemical defence ecology of marine unicellular plankton: constraints, mechanisms and impacts. Biol Bull 198:225-244

Submitted: April 20, 2012; Accepted: October 12, 2012

Proofs received from author(s): February 1, 2013 